\title{
北海道のスズメにおける嘴基部の色の季節変化と外部計測値に よる性判定の可能性
}

\author{
玉田克巳 ${ }^{1} \cdot$ 池田徹也 $^{2}$ \\ ${ }^{1}$ 北海道立総合研究機構 環境・地質研究本部 環境科学研究センター 自然環境部 生物多様性保全グループ \\ 道南地区野生生物室％ 043-0044 北海道檜山郡江差町字橋本町 72-1 \\ 2 北海道立衛生研究所 $\overline{\mathrm{T}}$ 060-0819 北海道札幌市北区北 19 条西 12 丁目
}

（2018 年 2 月 24 日受付； 2019 年 4 月 27 日受理）

キーワード：嘴, 性判定, 自然翼長, スズメ, 齢判定.

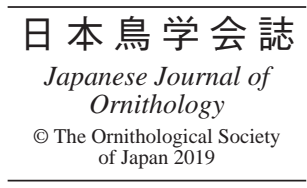

Katsumi TAMADA ${ }^{1}$, Tetsuya IKEDA². Seasonal change in basal bill colour and possibile sex discrimination based on exposed measurements of Eurasian Tree Sparrows in Hokkaido. Jpn J Ornithol 68: 349-355. (2019)

\begin{abstract}
During ringing of Eurasian Tree Sparrows Passer montanus in Hokkaido, three adult birds were recaptured. The colour of the basal part of the bill was black in one individual and yellow in two. Field studies show that juveniles have yellow bills, but both adults and young have black bills during June and July. From September to December, all birds developed yellow on their bills indicating seasonal change in bill colour. Male sparrows were significantly heavier with longer natural wing and tail lengths than females. Sex can be distinguished by a natural wing length of $67.7 \mathrm{~mm}$ and the probability of correct discrimination was $90 \%$.
\end{abstract}

Key words: Bill, Sex discrimination, Natural wing length, Passer montanus, Age determination.

${ }^{1}$ Southern Hokkaido wildlife research station, Nature Conservation Research Division, Institute of Environmental Sciences, Environmental and Geological Research Department, Local Independent Administrative Agency, Hokkaido Research Organization, Hashimotochou 72-1, Esashi, Hokkaido 043-0044, Japan.

${ }^{2}$ Hokkaido Institute of Public Health, Kita-19 Nishi-12 Kita-ku, Sapporo, Hokkaido 060-0819, Japan.

はじめに

スズメ Passer montanus は留鳥として北海道から 沖縄まで全国に分布し（日本鳥学会 2012），人家 周辺に生息するもっとも身近な鳥類である。世界 的にはカムチャツカ半島からヨーロッパまで, ユーラシア大陸に広く分布し, ボルネオ島, スマ トラ島, ジャワ島などの熱帯や亜熱帯の地域にも 分布している (del Hoyo et al. 2009). 10 亜種に分 類されており, 日本に生息する亜種 P. m. saturatus

* E-mail: tamada@hro.or.jp doi:10.3838/jjo.68.349
は, サハリン，韓国，南千島列島，台湾，フィリ ピンなどにも生息している (del Hoyo et al. 2009). また，マイクロサテライトDNA を用いた分析か ら, 北海道の札幌市, 利尻島, 知床半島に生息す るスズメ個体群は, 本州の群馬県や京都府の個体 群とは遺伝的地理変異があることが明らかになっ ているが，函館市の個体群は群馬県や京都府と遺 伝的に近い特徵があることが明らかになっている （泉 2005）.

形態的には雌雄同色で，性的二型ははっきりし な い（山階 1941; del Hoyo et al. 2009; 河井 ら 2013). 国内では, スズメの外部計測值に関する研 
究は少なく, 秋田県の調査では, 自然翼長には重 複はあるものの, オスの方がメスより有意に長い ことが明らかになっている (Matsui et al. 2017). 韓国でも同様にオスの翼長が長いことが報告され ている (Pinowska et al. 1998)。 また，ハンガリー に生息する基亜種 P. m. montanus では，オスは翼 長のほかに, 嘴峰長, 嘴高, 嘴幅, 尾長, 跗蹠長, 体重が大きいことが報告されている (Mónus et al. 2011).

齢について, 山階（1941）には, 成鳥の嘴の色 については冬には带褐黒色, 春季以後には真黒色 になるのに対し，幼鳥については暗褐色で基部は 淡いと記述されており, 成鳥と幼鳥で觜基部の色 が異なることが示されている。叶内ら (2014) と 河井ら（2013）にも，齢判定の特徴として，成鳥 の嘴は黒色であるのに対して, 幼鳥の嘴基部は黄 色であると記述されている。一方で，ヨーロッパ の鳥類標識調査員に向けて, 形態の特徵を参考に するために書かれたSvensson（1992）には，スズ メの嘴についての記述はなく, 形態については, 完全換羽後は成鳥と幼鳥の区別はできないことが 記されている。また, 清棲 (1952) と del Hoyo et al.（2009）では，嘴は齢に関係なく，黒色である とあり，基部に黄色味があることは記述されてい ない.しかし, Cramp \& Perrins (1994) と Brazil （2009）には嘴は黒色であるが, 下顎側の基部が季 節によって黄色味を帯びることが記されている. また三上（2013）にも，成鳥の嘴は秋になると根 元が黄色になることが記述されている。このよう に，スズメの嘴基部が黄色味を带びることは，齢 によるものか，季節変化によるものか，さまざま な見解がある.

筆者らは，北海道の札幌市と江別市のスズメ個 体群を対象に，嘴基部の色に着目して鳥類標識調 査と野外観察を実施し, 嘴基部の色の変化につい て調べたので報告する。また鳥類標識調査におい て捕獲した個体を対象に外部計測值の性差を調べ, 札幌市と江別市に生息する個体群の状況を明らか にするとともに，他地域との比較を行い，判別分 析による性判定の可能性を検討したので，あわせ て報告する。

\section{方法}

\section{1）鳥類標識調査}

鳥類標識調査は, 2009 年 12 月に北海道環境科 学研究センター (現, 北海道立総合研究機構 環
境- 地質研究本部 環境科学研究センター, 以下道 環境研, 430.' $\left.\mathrm{N}, 141^{\circ} 20^{\prime} \mathrm{E}\right)$ の前庭で開始し, 2013 年 11 月からは江別市一番町 $\left(43^{\circ} 06^{\prime} \mathrm{N}\right.$, 14133'ㄹ) においても調査をはじめ, 2015 年 2 月 まで実施した。両地域ともに, 捕獲には箱落し罠 (草野ら 1981) と $36 \mathrm{~mm}$ メッシュで, 長さが 12 $\mathrm{m}$, 高さが約 $2.2 \mathrm{~m}$ のかすみ網（ATX）を 1-4 枚 用いた。

捕獲した個体は, 鳥類標識調査用の足環を装着 したのちに, 自然翼長, 尾長, 跗蹠長, 露出嘴峰 長をダイヤルノギスで $0.1 \mathrm{~mm}$ の精度で, 体重を 電子天秤で $0.1 \mathrm{~g}$ の精度で測定した。 また嘴基部 の色を記録し、デジタルカメラで頭部を撮影した のちに放鳥した。嘴基部は，わずかでも黄色や淡 い黄白色の部分があった個体は黄色と判定し, 黄 色い部分が全くない個体は黒色と判定した。捕獲 した個体は 1 羽ずつ洗濯後の新しい鳥袋に入れて 作業を行い, 作業後の鳥袋内に捕獲個体の羽毛が あった場合は、これを採取した。採取した羽毛は， Griffiths et al. (1998) の方法にしたがって, DNA による性判定を行った，性が判定できた個体の計 測值を用いて, 外部計測值の性差を検討し, 変数 増減法による判別分析によって性判定の可能性を 検討した，再捕獲された個体の計測值は, 再捕獲 時の計測值のみを分析に用い, 新放鳥時の計測值 は分析には用いなかった。また，鳥類の体重は同 一個体でも季節や日内で変化することから（山階 鳥類研究所 2009), 判別分析にあたって, 体重を 除く 4 つの計測部位を説明変数とした。外部計測 值の性差は, 石居（1975）にしたがって $t$ 検定を 行い, 判別分析については統計ソフト EXCEL 多 変量解析 Ver.3.0（株式会社エスミ）を用いて分析 した。

\section{2）野外観察}

スズメの嘴基部の色を観察するために, 2014 年 6 月から 2015 年 5 月まで各月の中下旬に 1-3 日の 野外観察を実施した。野外観察はスズメを比較的 近距離で観察できる JR 札幌駅南口 $\left(43^{\circ} 04^{\prime} \mathrm{N}\right.$, $\left.141^{\circ} 21^{\prime} \mathrm{E}\right)$, 北海道庁の前庭 $\left(43^{\circ} 03^{\prime} \mathrm{N}, 141^{\circ} 20^{\prime} \mathrm{E}\right)$, 北海道大学構内 $\left(43^{\circ} 04^{\prime} \mathrm{N}, 141^{\circ} 20^{\prime} \mathrm{E}\right)$ の 3 か所で 実施した。JR 札幌駅南口と北海道庁の前庭ではド バトColumba livia が生息しており，鳥類への飭や りを禁止する看板は揭出されているが，一部の市 民によって慨付けが行われている. 北海道大学構 内では餌付けはほとんど行われていないが, 都市 緑地になっており，比較的多くのスズメが近距離 
で観察できる，調査にあたっては，一定のルート は設定せず，3 か所の調査地を任意に歩いてスズ メを観察したが，月内では同じ場所を歩かないよ うにした，調査では，嘴基部の色が観察できた個 体だけを記録した。スズメまでの観察距離は約 15 $\mathrm{m}$ 以内で，スズメまでの距離が遠い場合や後ろ向 きの個体など，嘴の基部がはっきり観察できない 個体は記録しなかった。観察には 10 倍の双眼鏡を 用いたほか，望遠レンズ $(100-400 \mathrm{~mm})$ を装着し たデジタルカメラも併用した。

道環境研に設置した巣箱一つに扔いて，2011 年 にスズメが繁殖したが，この年の観察では，5月 中旬に産卵して，6月中旬に巣立ちした。この巣 箱では 2 回目の繁殖が確認され，6月下旬に産卵， 7 月下旬に巣立ちが確認された (玉田未発表)。た だし親鳥には足環を装着していないため，同じ個 体であるかは確認できていない，1例の観察記録 であるが，巣箱での繁殖状況から，野外観察を開 始した 6 月中下旬は, この調查地周辺では 1 回目 の繁殖でヒナが巣立ちする時期に相当し, 調査を 終了した 5 月中下旬は, 1 回目の繁殖の抱卵, 育 雛中であり，ヒナが巣立つ前の時期に相当すると 考えられる。

幼鳥の定義はさまざまあるが，本研究では高木 （2004）にしたがって, 巣立時期に真羽を獲得した 羽衣から第一回冬羽に換羽するまでとした。この 定義では，第一回冬羽から第一回夏羽までの個体 は若鳥と区分している，巣立ち後のスズメでは，7 月下旬から 11 月上旬に一回目の換羽があるが（橋 本 1962), 換羽後の若鳥は, 成鳥と同色になるた め, 成鳥と若鳥の区別ができない (Svensson 1992)。野外観察では, 6-8 月の観察では, 羽色と 給餌行動から幼鳥を識別し, それ以外の個体を成 鳥・若鳥と区分した．9月以降の観察では，著者 らには外部形態から成鳥, 若鳥, 幼鳥を区別する ことは困難であったため, すべて齢不明として取 り扱った。

\section{結果}

\section{1）再捕獲個体の嘴基部の色}

新放鳥したスズメは，道環境研では 51 羽，江別 市では 13 羽で，合計 64 羽であった。 2012 年と 2013 年に道環境研において 3 羽が再捕獲された。 2011 年 2 月 22 日に捕獲した個体の嘴基部は黒色 であったが（足環番号 3C46387，性，齢不明，図 1a), この個体は 1 年 1 か月後の 2012 年 3 月 2 日
に再捕獲され，この時点で嘴基部の色は黒色のま まであった（図 1b).2012 年 8 月 22 日に捕獲した オス幼鳥の嘴基部は黄色であったが（足環番号 3C46418, 図 1c), この個体は 1 年 3 か月後の 2013 年 11 月 29 日に再捕獲され, 嘴基部は黄色のまま であった（図 1d）。2013 年 4 月 3 日に捕獲された メ久の嘴基部は黒色であったが（足環番号 3C46444, 齢不明, 図 1e), 8 か月後の 2013 年 12 月 17 日に再捕獲された時点で嘴基部の色は黄色に 変化していた（図1f）。

\section{2）野外観察個体の嘴基部の色}

野外観察で確認した嘴基部の季節変化を図 2 に 示す、調査を開始した 6 月と 7 月は，観察できた 成鳥・若鳥, のべ 132 羽の嘴基部はすべて黒色で, 幼鳥のべ 122 羽はすべて黄色であった， 8 月は, 観察できた幼鳥 82 羽はすべて黄色であったが, 成 鳥・若鳥でも黄色の個体が確認されるようになり， その割合は $81 \%$ と多かった。 9 月から 12 月に観察 できた齢不明の個体のべ 273 羽の嘴基部は, 11 月 の 1 羽を除いて，すべて黄色であった。 1 月と 2 月には黒色の個体が確認されるようになり, その 割合はそれぞれ 8\%と 71\%で，黒色の個体が増加 し, 3 月から 5 月にかけて確認された齢不明の個 体のべ 273 羽は, すべて黒色であった.

\section{3）捕獲個体の計測値と判別分析}

捕獲した個体のうち，40 羽で性判定ができた。 計測值が得られた個体数は, オスが 15 羽, メスが 25 羽であり，再捕獲個体を除いて，すべて齢不明 である。計測值の分析に用いた個体が捕獲された 期間は 11 月から 4 月までである。

各計測值の平均值を表 1 に示した。体重, 自然 翼長，尾長はオスの方が有意に大きかった（ $t$ 検 定, 体重 : $t=2.3, P<0.05$; 自然翼長 : $t=6.6, P<$ 0.01 ; 尾長 : $t=3.7, P<0.01)$. 露出嘴峰長と跗蹠長 は統計的に有意ではなかった（露出嘴峰長 : $t=$ $0.9, P>0.05$; 跗蹠長 : $t=1.2, P>0.05)$. 判別分析 を行った結果, 以下の式が得られた。

\section{$\mathrm{Z}=1.795827 \times \mathrm{WL}-121.526$}

$(\mathrm{Z} \geqq 0$ の場合はオス, $\mathrm{Z}<0$ の場合はメス, $\mathrm{WL}$ : 自然翼長, $\left.F_{1,38}=43.62, \quad P<0.01\right)$

選択された変数は自然翼長だけであり, $67.7 \mathrm{~mm}$ 闇值であった，判別的中率は $90 \%$ と計算され（表 2), $67.5 \mathrm{~mm}$ と $66.2 \mathrm{~mm}$ のオスが各 1 羽, $68.8 \mathrm{~mm}$ 


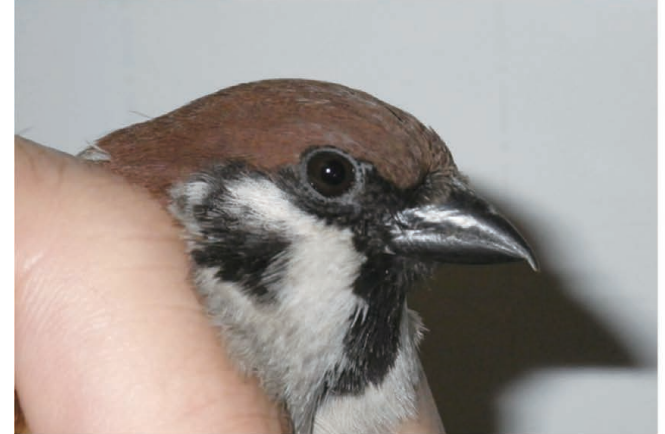

：3C46387，性不明 (Sex Unknown), 22-Feb-2011.

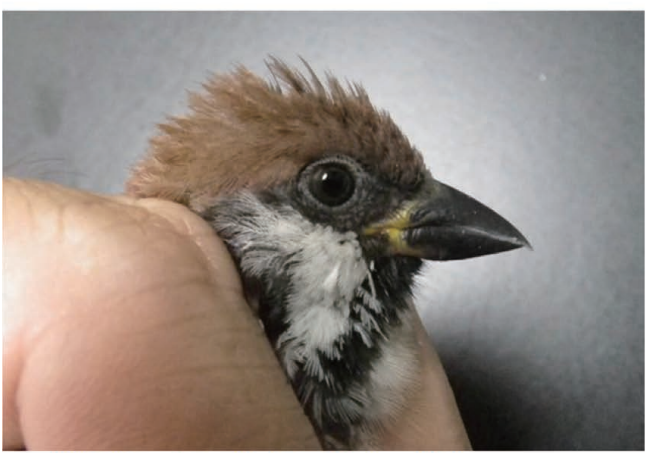

c : 3C46418, オス (Male), 22-Aug-2012.

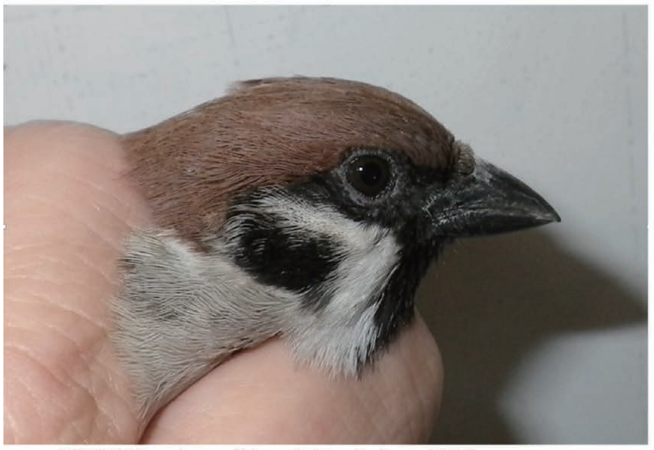

e : 3C46444, メス (Female), 3-Apr-2013.

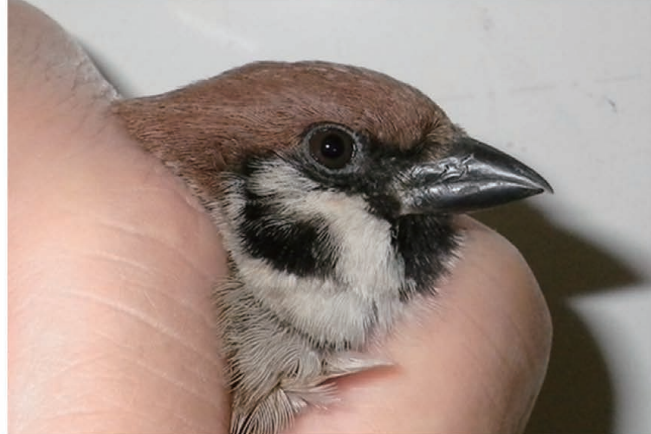

b : 3C46387, 性不明 (Sex Unknown), 2-Mar-2012.

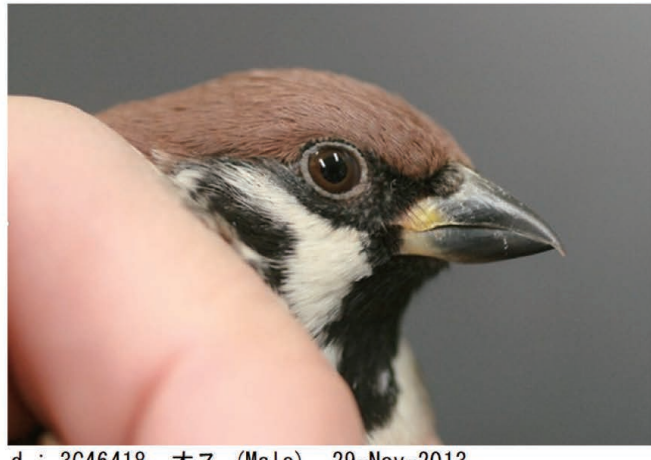

d : 3C46418, オス (Male), 29-Nov-2013

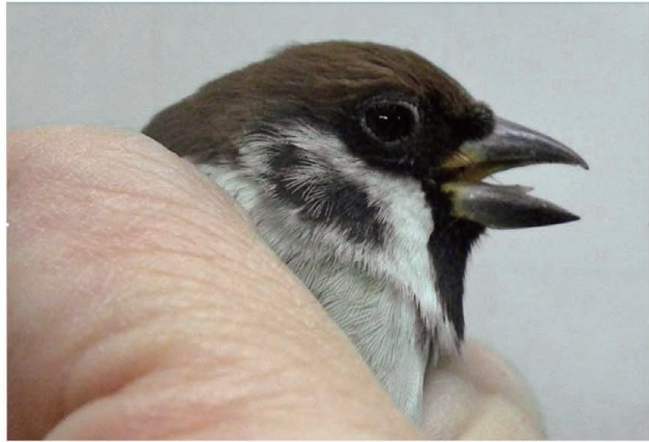

f : 3C46444, メス (Female), 17-Dec-2013.

図 1. 再捕獲された個体の新放鳥時と再捕獲時の頭部写真.

Fig. 1. Photographs of re-captured sparrows at the time of release and re-capture.

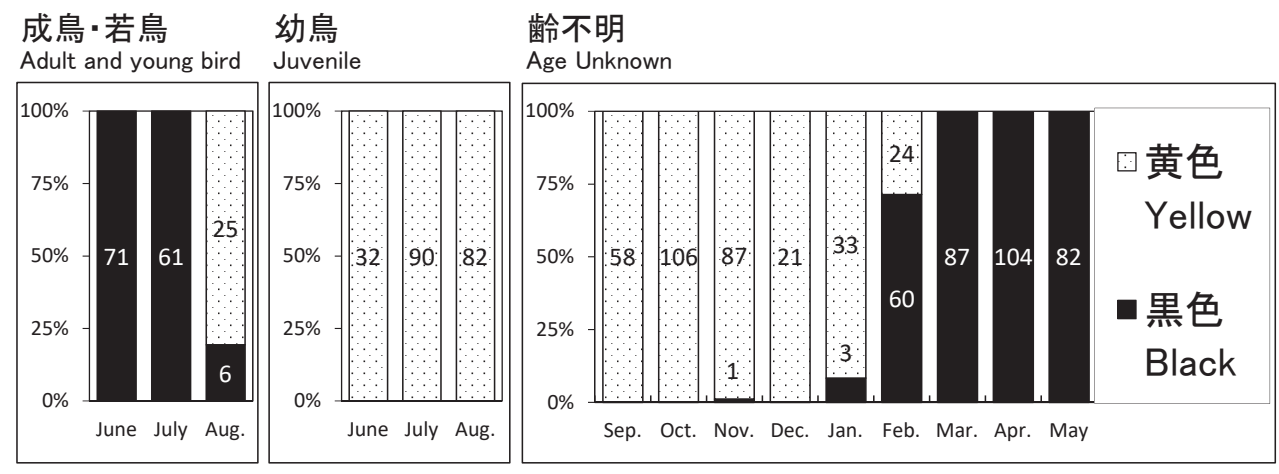

図 2. 野外観察による嘴基部の色の季節変化. 数字は確認した個体数.

Fig. 2. Seasonal change in basal bill colour. Numbers indicate birds observed. 
表 1. スズメの外部計測值。平均值 標準偏差，括弧内は範囲を示す。性差は $t$ 検定で分析した.

Table 1. External measurements of Eurasian Tree Sparrows. Means are given with \pm standard devision. Range is given in parentheses. Sexual differences were examined by $t$-test.

\begin{tabular}{lcccc}
\hline \hline & オス (Males) $n=14$ & メス (Females) $n=23$ & $t$-value & $P$-value \\
\hline 体重 Body Mass (g) & $25.2 \pm 1.6(22.5-28.1)$ & $23.9 \pm 1.5(20.8-26.4)$ & 2.4 & $<0.05$ \\
露出嘴峰長 Bill Length (mm) & $12.2 \pm 0.6(11.1-13.2)$ & $12.1 \pm 0.5(11.0-12.8)$ & 0.7 & $>0.05$ \\
自然翼長 Natural Wing Length (mm) & $69.0 \pm 1.3(66.2-71.2)$ & $66.3 \pm 1.1(64.1-68.8)$ & 6.6 & $<0.01$ \\
尾長 Tail Length (mm) & $56.7 \pm 1.5(53.4-58.8)$ & $54.6 \pm 1.7(52.0-59.2)$ & 3.8 & $<0.01$ \\
跗蹠長 Tarsus Length (mm) & $18.2 \pm 0.4(17.8-19.0)$ & $18.0 \pm 0.5(16.6-18.8)$ & 1.4 & $>0.05$ \\
\hline
\end{tabular}

表 2. スズメの外部計測值にかかる判別クロス表. Table 2. Discrimination cross table of external measurements of Eurasian Tree Sparrows.

\begin{tabular}{lccc}
\hline \hline & $\begin{array}{c}\text { オス } \\
\text { (Males) }\end{array}$ & $\begin{array}{c}\text { メス } \\
\text { (Females) }\end{array}$ & $\begin{array}{c}\text { 全体 } \\
\text { (Total) }\end{array}$ \\
\hline $\mathrm{Z} \geqq 0$ & 13 & 2 & 15 \\
$\mathrm{Z}<0$ & 2 & 23 & 25 \\
\hline 全体 (Total) & 15 & 25 & 40 \\
\hline
\end{tabular}

と $68.1 \mathrm{~mm}$ のメスが各 1 羽の合計 4 羽が誤判定さ れた。

\section{考察}

再捕獲された 3 個体のうち, 3C46387 と 3C46418 の 2 個体は, 新放鳥から 1 年以上が経過 しているので，再捕獲の時点では成鳥である，巣 箱で繁殖した個体の状況から, 調查地周辺では 1 回目繁殖の捊化日は 5 月下旬ごろ, 2 回目繁殖の 孵化日は 7 月上中旬ごろと推定できる。新放鳥か ら8 か月で再捕獲された 3 C46444 は, 新放鳥され た 2013 年 4 月時点での年齢は明らかではないもの の，2013 年より前に生まれた個体であることは明 らかであり，この個体についても再捕獲の時点で は 1 歳以上の成鳥である。再捕獲された 3 個体の 嘴基部の色は黄色の個体と黒色の個体が存在し, 1 羽であるが黒色から黄色に変化した個体が存在し た，野外観察の調查結果から，スズメの嘴基部の 色は季節変化することが考えられ，9月から 12 月 は，ほとんどすべての個体で嘴基部は黄色であり， 3 月から 5 月はすべての個体が黒色である。1 月か ら 2 月は黄色から黒色に変化する時期で, 8 月は 黒色であった成鳥が黄色に変化する時期であると 思われる。このことから, 嘴基部が黄色のスズメ をすべて幼鳥と判定することは誤りである.

橋本（1962）は, 三重県において散弾銃などで 捕獲したスズメを調べ，嘴基部の色が季節によっ
て変化することを記述している，これによると成 鳥については, 繁殖期の 5-6 月の嘴は黒色である が, 早いものでは 7 月下旬から口角付近と嘴底に 淡色部が現れ，8月中旬から 9 月中旬には幼鳥と 同じ形色になるとしている，そして 10 月から成鳥 の嘴は黒色になることから，10月から翌年 3 月ま での若鳥と成鳥は嘴色の違いを根拠に識別できる としている。本研究の野外観察の結果では，9月 から 12 月に観察したのべ 273 羽の齢不明個体は, 1 羽を除いて嘴の色はすべて黄色であった。この 11 月に嘴の色が黒色であった 1 羽だけが成鳥で, のべ 272 羽がすべて若鳥であったとは考えにくく， 9 月から 12 月に観察した嘴基部が黄色ののべ 272 羽の個体のなかには成鳥も存在するものと考えら れる. 三重県では, 北海道の本研究と比べて秋か ら冬にかけての嘴の色の変わり方が異なっている ことがうかがえる。 マイクロサテライト DNAの 分析から, 函館を除く北海道のスズメは, 群馬県 や京都府の個体群とのあいだには遺伝的変異があ ることが報告されており（泉 2005）, 今回のこの 違いは個体群の違いによる可能性が考えられる。 ただし，橋本（1962）には，捕獲個体を嘴の色以 外に具体的にどのような特徽に基づいて成鳥と若 鳥を識別したかについての記述がないため, 嘴色 の違いをもとに成鳥と若鳥を識別できるとするこ の記述は，根拠がはっきりしない．

山階（1941）は, 幼鳥の嘴基部は淡く, 成鳥の 嘴は黒色であるとしている，幼鳥を，第一回冬羽 に換羽が終了する 11 月下旬までとすると，今回の 野外観察の結果からも，6-8 月までの幼鳥と 9-12 月までの齢不明のほとんどの個体は嘴基部が黄色 であったので, 幼鳥の嘴基部は淡いという記述は 正しいことになる。しかし, 今回の再捕獲の個体 では 1 歳以上の成鳥で嘴基部が黄色の個体も確認 されており, 山階 (1941) の成鳥の嘴基部は黒色 であるとする記述は，すべての個体で当てはまる ことではない，また，嘴基部の色を成鳥と幼鳥の 
識別ポイントとして指摘している叶内ら (2014) と河井ら（2013）の記述は，6-7 月の巣立ち直後 の時期に限られたことであると考えられる。

Cramp \& Perrins（1994）は，スズメの成鳥の嘴で は繁殖期の前には黒色になるが, 繁殖期以外では 鈍い茶褐色で, 下顎の嘴基部に黄色を帯びること が記述されている，今回の野外観察でも，嘴基部 の色は 1-2 月には黄色と黒色の個体が混在するが, 3 月から 5 月までの齢不明個体と，6-7 月の成鳥・ 若鳥はすべて黒色であったことから, Cramp \& Perrins（1994）の季節についての記述とほぼ一致 した. Brazil (2009) には, スズメの嘴は, 夏には 黒色であるが，冬には下顎の下側の基部が黄色で あると記述され拉り，黒色と黄色になる季節は少 しずれているが，季節変化することを指摘してい る.しかし, これらの 2 つの先行研究と比べて, 本研究では, 黄色になるのは下顎の嘴基部だけで なく, 上顎側の嘴基部も黄色になる点では一致し ていなかった．また三上（2013）にも成鳥の嘴は 秋になると根元が黄色になることが記述されてお り, 本研究の結果と矛盾しない. 清棲 (1952) と del Hoyo et al. (2009) には, スズメの嘴について は，黒色と記述されているだけで，季節変化に関 する記述はない。

今回の調査結果から, 北海道に生息するスズメ の成鳥には嘴基部の色が黄色と黒色の個体が存在 することが明らかになり，色は季節によって変化 することが考えられた。このため，成鳥と幼鳥の 識別点として, 嘴基部の色に着目することは, 巣 立ち直後の限られた期間ではあてはまるものの，8 月以降ではあてはまらないと考えられる。北海道 では，10月から 12 月にかけては，ほとんどすべ ての個体で嘴基部は黄色になるが, 三重県の先行 研究の結果と異なるところがある。今後は本州以 南を中心に, 各地でスズメの嘴の色に着目した調 查研究を進め, 情報を収集していくことが必要で ある。

北海道における本研究の外部計測值の結果では, 体重, 自然翼長, 尾長でオスの方が有意に大きい ことが明らかになった。今回，計測值の分析に用 いた個体が捕獲されたのは 11 月から 4 月までの期 間である，捕獲個体についてはほとんどすべての 個体が齢不明であり，1歳未満の個体も含む值で あるが，ほとんどすべてが第一回冬羽に換羽して 以降の個体である。サンプル数は十分とは言えな いが，判別分析の結果から，自然翼長が $67.7 \mathrm{~mm}$ を境界值として，90\%の個体が性判定できること
が明らかになった. Matsui et al. (2017) は秋田県 大潟村で捕獲した 49 羽のスズメから外部計測值の 性差を検討しているが, 有意差が認められたのは 自然翼長だけで, 体重, 跗蹠長, 尾長では有意差 は認められなかった。また韓国においては翼長に は有意差があったが, 尾長と跗蹠長には差がな かったことが明らかになっている (Pinowska et al. 1998)。秋田県と韓国の調査は, 5 月から 8 月まで の繁殖期から夏季の成鳥を対象にした調査である. 秋田県と韓国で尾長に差が認められなかったこと は, 北海道との地域の差である可能性と, 調査し ている季節の違いである可能性が考えられる。こ のほかハンガリーの基亜種 (P. m. montanus) にお いては翼長, 尾長, 跗蹠長, 嘴高, 嘴幅に差が あったことを報告されており，翼長から 90.2\%の 確率で性判定ができることが報告されており (Mónus et al. 2011), 本研究の結果と酷似してい た。ただし，ハンガリーの調査は 10-11月の成鳥 を対象にしているが, 本研究に比べて, 翼長の平 均值が, オスで $4.0 \mathrm{~mm}$, メスで $3.7 \mathrm{~mm}$ 大きいた め, 最大翼長の結果と思われる. 北海道で行った 本研究と, 秋田県, 韓国, ハンガリーの先行研究 をあわせて，4 地域のすべてで，スズメの翼長は， オスがメスより有意に大きいことが明らかになっ た.しかし, 尾長や跗蹠長については, 調査の結 果に差があった。これらの違いについては, 地域 の差だけではなく, 調査時期, 調査方法も併せて, 今後, 注意深く検討することが必要である.

調査を進めるにあたり，泉 洋江氏には一部の個体の 性判定を実施していただいた。 3 名の匿名の查読者には 有意義な意見をいただいた。また，編集委員会の植田睦 之委員長と藤田 摒副委員長には有意義な意見をいただ いたほかに, 本稿を丁寧かつ迅速に取り扱っていただい た。記してお礼申し上げる。

\section{摘要}

北海道においてスズメ Passer montanus を対象と した鳥類標識調査を実施して, 8 か月以上経って から成鳥 3 羽を再捕獲した。嘴基部の色は， 1 羽 が黒色で，2 羽が黄色であった。 野外観察の結果 から, 6 月から 7 月までの間, 幼鳥の嘴基部の色 は黄色であったが, 成鳥は黒色であった，9月か ら 12 月は，ほとんどすべて個体が黄色になり， 1-2 月には黒色の個体の割合が増加し，3-5 月に はすべて黒色であった．このことから嘴基部の色 は，季節変化することが考えられた。 オスの計測 值は, 体重, 自然翼長, 尾長で有意に大きかった. 
自然翼長は $67.7 \mathrm{~mm}$ を境界值として性判定ができ, 誤判別率は 90\%であった。

\section{引用文献}

Brazil M (2009) Birds of East Asia. Princeton University Press, Princeton.

Cramp S \& Perrins C (eds) (1994) Handbook of the Birds of Europe, the Middle East and North Africa Vol 8. Oxford University Press, Oxford.

del Hoyo J, Elliott A \& Christie D (eds) (2009) Handbook of the Bird of the World. Vol. 14, Old World Sparrows. Lynx Edicions, Barcelona.

Griffiths R, Double MC, Orr K \& Dawson RJG (1998) A DNA test to sex most birds. Mol Ecol 7: 1071-1075.

橋本太郎 (1962) 農村地帯に於けるスズメ群の生態。鳥 17: 163-171.

石居 進 (1975) 生物統計学入門 一具体例による解説と 演習一。培風館, 東京.

泉 洋江 (2005) スズメ。バードリサーチニュース 2(4)： 4-5.

叶内拓哉 · 安部直哉 ·上田秀雄 (2014) 新版 日本の野鳥. 山と溪谷社, 東京.

河井大輔 · 川崎康弘 ·島田明英 ·諸橋 淳 (2013) 新訂 北海道野鳥図鑑. 覀璃西社, 札幌.

清棲幸保 (1952) 日本鳥類大図鑑 I 。講談社, 東京.

草野忠治·芳賀良一・森 樊須 - 石橋信義 (1981) 応用
動物学. 朝倉書店, 東京.

Matsui S, Kasahara S, Kato T, Izumi H, Morimoto G, Ueda K \& Mikami OK (2017) Badge size of male Eurasian tree sparrows Passer montanus correlates with hematocrit during the breeding season. Ornithol Sci 16: 87-91.

三上 修 (2013) スズメ一つかず・はなれず・二千年. 岩波書店, 東京.

Mónus F, Szabó K, Lózsa A, Pénzes Z \& Barta Z (2011) Intersexual size and plumage differences in Tree Sparrows (Passer montanus) - a morphological study based on molecular sex determination. Acta Zool Hung 57: 269276.

日本鳥学会 (2012) 日本鳥類目録改訂第 7 版. 日本鳥学 会, 三田.

Pinowska B, Pinowski J \& Hahm KH (1998) Tree sparrows (Passer montanus saturates Stenjneger 1886) can be sexed on the basis of plumage characteristics. International Studies on Sparrows 25: 51-55.

Svensson L (1992) Identification Guide to European Passerines, fourth, revised and enlarged edition. Published by the author, Stockholm.

高木昌興 (2004) 幼鳥. 山岸 哲. 森岡弘之 · 樋口広芳 (監) 鳥類学辞典：821. 昭和堂, 京都.

山階鳥類研究所 (2009) 鳥類標識マニュアル改訂第 11 版. 山階鳥類研究所, 我孫子.

山階芳麿 (1941) 日本の鳥類と其の生態 第一巻. 梓書 房, 東京。 